\title{
ラジオイムノアッセイ法を用いた慢性腎不全患者の 血墏エリスロポイエチン濃度
}

\author{
大東貴志橘政昭出口修宏田崎寛
}

慶応義塾大学泌尿器科

(昭和 63 年 2 月 5 日受付)

key words : erythropoietin, chronic renal failure, radioimmunoassay

〈要旨〉

血液透析をうけている慢性腎不全患者の血漿エリスロポイエチン（EPO）濃度を測定し, 正常対照群と比較すると ともに，様々な因子との関係を検討した，対象は 3 カ月以上血液透析を受けている慢性腎不全患者 67 例と, 正常対照 者 16 例で, 測定は人精製 EPO を家兔に免疫して得られた抗 EPO 抗体を用いたラジオイムノアッセイ法により行なっ た.

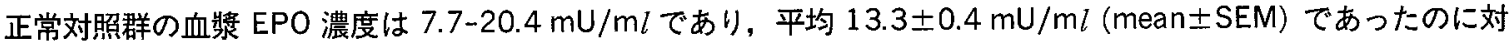

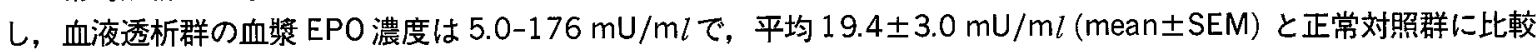
して有意に高值を示した $(p<0.05)$. 血液透析群の年齢, 性, 未梢血へマクトリット值, へモグロビン濃度と血漿 EPO 濃度との検討では，とれどれとの間に統計学的に有意な相関関係は得られなかったが, 血液透析期間との間に正の相 関が認められた $(r=0.41)$. 慢性腎不全の原因疾患と血漿 EPO 濃度との検討では, 多囊胞腎患者が他の原因による ものと比較して有意に高値であった $(p<0.05)$.

以上のことより, 慢性腎不全患者の血漿 EPO 濃度は対照群と比較してむしろ高值であり，また原因疾患によって も異なることから, その貧血の治療に際しては, 血漿 EPO 濃度に基づいて治療方針を立てることが重要と思われた.

\section{Plasma erythropoietin concentration in chronic renal failure measured by radioimmunoassay}

Takashi Ohigashi, M. D., Masaaki Tachibana, M. D., Nobuhiro Deguchi M. D., Hiroshi Tazaki M. D. Department of Urology, School of Medicine, Keio University

We studied plasma erythropoietin (EPO) concentration in patients with chronic renal failure who underwent regular hemodialysis. Plasma EPO concentration was measured in 67 hemodialysis patients and 16 normal controls by radioimmunoassay using anti-EPO antibody derived from rabbits immunized with human recombinant EPO.

Plasma EPO concentration in dialysis patients was $19.4 \pm 3.0 \mathrm{mU} / \mathrm{m} l$ (mean $\pm \mathrm{S}$. E. M., range 5.0-176), significantly higher than the mean value of normal controls ; $13.3 \pm 0.4 \mathrm{mU} / \mathrm{m} l$ [range 7.7-20.4] $(p<0.05)$. There was no significant difference in plasma EPO between male and female dialysis patients, and plasma EPO did not correlate with hematocrit, hemoglobin concentration or age. However, the length of hemodialysis showed a positive correlation with plasma EPO $(r=0.41)$. Polycystic kidney disease patients manifested higher plasma EPO concentration than other kidney disease patients $(p<0.05)$.

In conclusion, because plasma EPO concentration in hemodialysis patients was higher than in normal controls and showed differences in various diseases with renal failure, it is important that it be considered in the treatment of patients with anemia due to chronic renal failure.

大 東 貴 志 慶応義塾大学泌尿器科

个 160 新宿区信濃町 35 (03-353-1211)
緒言

慢性腎不全 (CRF) 患者の貧血, いわゆる腎性唄血の 
原因は，主にエリスロポイエチン（EPO）産生の減少と 血中に存在する造血阻害物質によるものと考えられてい る1). 近年まで純化 EPO の精製が困難であったために, ラジオイムノアッセイ(RIA)㹥限られた施設でのみしか 行兄す2 ${ }^{2 \sim 5}$, 血液中の $\mathrm{EPO}$ 濃度の測定は，感度の低く他 の要因の影響を受けやすいバイオアッセイ法によること が多かった ${ }^{6 \sim 10)}$.これらの方法を用いた CRF 患者の $\mathrm{EPO}$ 活性に関する研究では, その値が必ずしも低值では ないとの報告も見られ，賽血との関係も明かではなかっ $た^{8 \sim 10)}$.

しかし 1985 年に, EPO のクローニングが成功し11 recombinant EPO (rEPO) の大量生産が可能となった ため，これを用いた比較的簡易な RIA による EPO の 測定が可能となってきた.

本研究では，CRF により血液透析 (HD) を受けてい る患者の血漿中の EPO 濃度を RIA により測定し, 正 常対照群と比較するとともに，慢性腎不全患者における 負血及び他の因子と EPO の関係につき検討を行なうこ とを目的とした。

\section{方法}

\section{1. 対象}

血液透析 (HD) 群：CRF で定期的に血液透析を受け ている患者 67 人の血漿中 $\mathrm{EPO}$ 濃度を測定した. 男性が 40 人, 女性が 27 人で, 年龄は 34 歳から 80 歳まで分布し て极り平均は $48.1 \pm 1.2$ 歳 (mean士SEM) であった。患 者は，週に 2 回ないし 3 回の透析を受けており，測定時 までの血液透析歴は 3 力月から 132 力月で平均 $48.0 \pm$ 8.4 カ月 $($ mean $\pm \mathrm{SEM})$ であった. CRF の原因疾患は, 慢性腎炎 40 人, 糖尿病性腎症 9 人, 高血圧性腎症 6 人, 多䇾胞腎 4 人，ループス腎炎 2 人，妊娠中毒症 1 人，薬 剂性急性系球体壞死 1 人，その他不明 4 人であった。輸 血による影響を除外するために，測定前 3 力月間に輸血 をした者は含まれず，また自己腎を摘出しているものは 1人もいなかった。

対照群: 正常対照群 16 人の内訳は, 男性 13 人, 女性 3 人で, 年齢法 12 歳から 77 歳まで分布しており平均 $56.6 \pm 4.9$ 歳 (mean \pm SEM) であった。

\section{RIA}

HD 群では血液透析の直前に, 対照群では早朝空腹時 に採血した血液をEDTA-2 Na に添加し，血墏分離した ものをー $30^{\circ} \mathrm{C} て ゙$ 涷結保存した. RIA は, Garcia, Sherwood, Goldwasserの方法 ${ }^{12} に$ 準じて行なった. 今回の 研究に用いた $\mathrm{rEPO}$ は，キリンビール株式会社より供与 されたもので, 濃度は 5,000 units $/ \mathrm{m} l$ に調節されている. ${ }^{125} \mathrm{I}-\mathrm{Na}$ を用いた EPO のヨード化は，NEN 社のキット を用い，ラクトペルオキシダーゼ法により行なった，抗

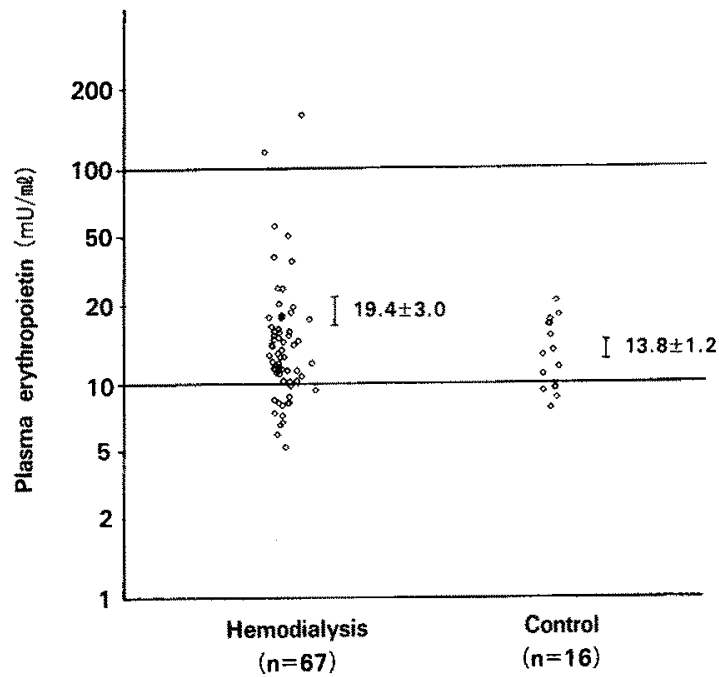

図 1 Plasma erythropoietin concentrations in patients receiving hemodialysis treatment and healthy controls (values are mean \pm S.E.M)

$\mathrm{EPO}$ 抗体は, $\mathrm{rEPO}$ を家鬼に免疫して得られたもので, キリンビール株式会社より供与された。

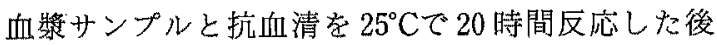
に, ${ }^{125} \mathrm{I}-\mathrm{EPO}$ を加え, 再度 $25^{\circ} \mathrm{C}$ 下で 20 時間反応した。 bound/free 分離をポリエチレングリコール法により行 ない, free ${ }^{125}$ 省除去した。 あらかじめ濃度を調整した rEPO を用いて作成した標準曲線により, サンプルの $\mathrm{EPO}$ 濃度を測定した。

\section{結果}

両群の血獎 EPO 濃度の分布を図 1 に示した. HD 群 の血漿 $\mathrm{EPO}$ 濃度の平均値は, $19.4 \pm 3.0 \mathrm{mU} / \mathrm{m} l$ (mean \pm $\mathrm{SEM})$ で, 最低 $5.0 \mathrm{mU} / \mathrm{m} l$, 最高 $176 \mathrm{mU} / \mathrm{ml}$ であった。 一方対照群の平均血漿 $\mathrm{EPO}$ 濃度は, $13.3 \pm 0.4 \mathrm{mU} / \mathrm{m} l$ で あり, (範囲 : $7.7 \mathrm{mU} / \mathrm{m} l-20.4 \mathrm{mU} / \mathrm{m} l) \mathrm{HD}$ 群で有意に 高值であった $(\mathrm{p}<0.05)$.

$\mathrm{HD}$ 群の平均末梢血へマトクリット值は， $25.2 \pm 0.7 \%$ (mean $\pm \mathrm{SEM})$, 平均へモグロビン濃度は $7.8 \pm 0.2 \mathrm{~g} / \mathrm{d} l$ (mean $\pm \mathrm{SEM}) て ゙$, 対照群のそれぞれ $39.3 \pm 1.1 \%, 13.3 \pm$ $0.4 \mathrm{~g} / \mathrm{d} l$ と比較して低值であったが, 血墏 EPO 濃度と ヘマトクリット值およびへモグロビン濃度との間に有意 な相関は得られなかった（ $\mathrm{r}=0.14, r=0.12)$ （図 2， 図3).

$\mathrm{HD}$ 群の血漿 $\mathrm{EPO}$ 濃度は，男女間で差を認めず，(男 性 $19.2 \pm 4.3 \mathrm{mU} / \mathrm{ml}$, 女性 $19.6 \pm 4.1 \mathrm{mU} / \mathrm{m} l$ (mean士 $\mathrm{SEM})$ ) 年齢との相関も得られなかった $(r=0.17)$ （図 4). 


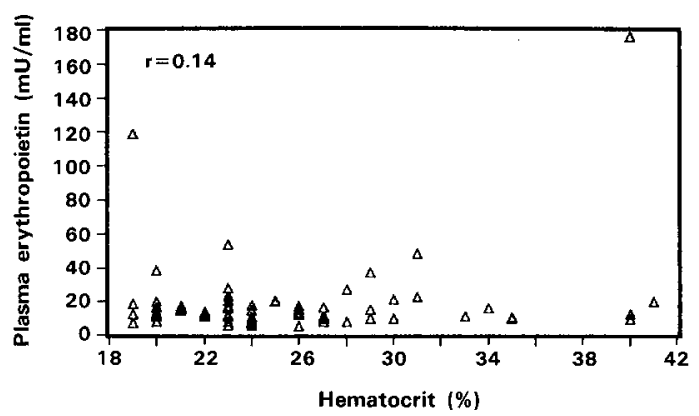

図 2 Relationship between hematocrit and plasma erythropoietin concentration in patients receiving regular hemodialysis

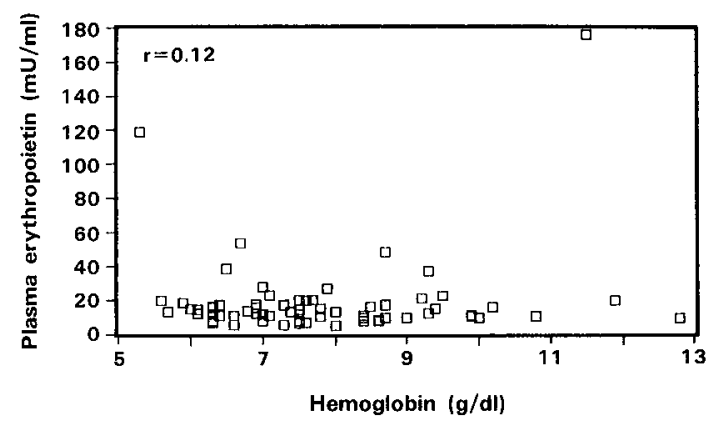

図 3 Relationship between hemoglobin and plasma erythropoietin concentration in patients receiving regular hemodialysis

しかし，血液透析期間と血漿 EPO 濃度に関しては， 透析期間の長い症例が, 血漿 EPO 濃度が高值を示す傾 向がみられた(図 $5, r=0.41, Y=5.27+0.29 \mathrm{X}, \mathrm{r}<$ 0.001)。血液透析期間と末梢血へマトクリット值，へモ グロビン濃度との間には有意な相関が得られなかった。

HD 群の原因疾患別に末梢血へマトクリット值および 血槳 EPO 濃度を比較してみる (図 6) と, 多囊胞腎 (PCD) が原因となっている患者の血墏 $\mathrm{EPO}$ 濃度が，他 群と比較して有意に高值であうた $(\mathrm{p}<0.05)$. 慢性腎炎, 糖尿病, 高血圧が原因となっているものは, 対照群と比 較しても血漿 EPO 濃度に有意の差が得られなかった。 末梢血へマトクリット值は各疾患の間で有意の差がみら れなかった。

\section{考察}

慢性腎不全患者の貧血は，血液透析により改善の傾向 が認められると報告されているが ${ }^{13)}$, 多くの患者は血液 透析導入後も依然として, 貧血の状態にとどまっている。 いわゆる腎性貧血の原因としては, 血清中の造血阻害物 質の存在 ${ }^{14 \sim 17)}$, 赤血球寿命の短縮 ${ }^{13)}$ などが考えられて

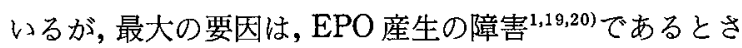

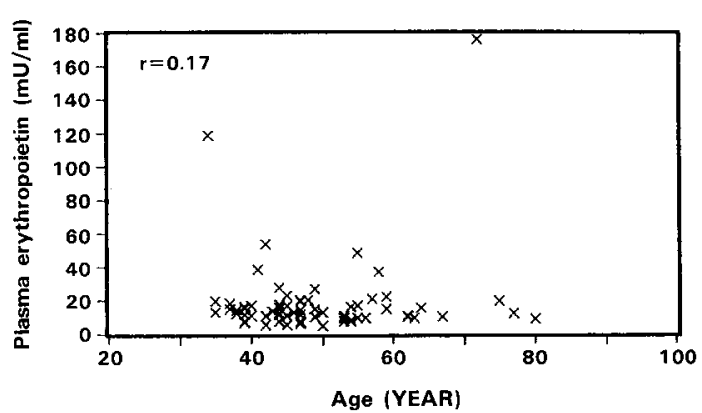

図 4 Relationship between age and plasma erythropoietin concentration in patients receiving regular hemodialysis

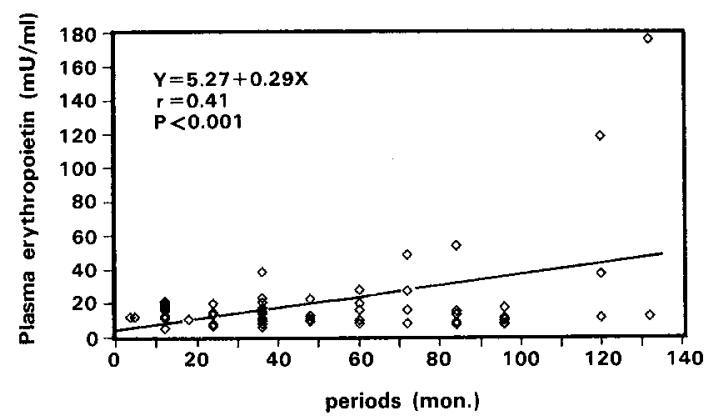

図 5 Relationship between periods of hemodialysis and plasma erythropoietin concentration
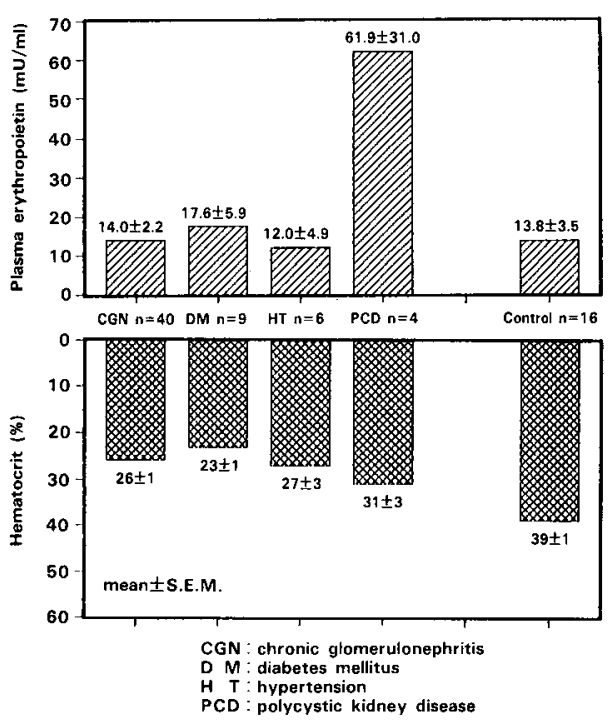

図 6 Mean plasma erythropoietin concentration and mean hematocrit in patients at various causes of CRF and in healthy controls 
れている. 近年, EPOのクローニングにより大量生産さ れた rEPOの投与が, 慢性腎不全患者の貧血の改善にき わ放で市ると報告されている(1,22)ことも，この事 を裹付けていると思われる。しかし，一口に慢性腎不全 といってもその病態，原因は様々であり，これらの筫血 に対する治療方針をたてる上に，血液中の EPO の状態 を知ることが重要であると思われる。

血液透析患者の EPO は，諸家により様々な方法で測 定されている. Caro らは，血液透析中の腎摘患者及び非 腎摘患者の双方の血清 EPO 活性を血清濃縮法を用いた 多血マウス法により測定し，正常群と比較したが，腎摘 患者では正常群より低值を示したのに対し，非腎摘患者 では平均で正常群を上回るものの高值群と低值群の二群 に分かれると報告している的. Fetal mouse liver cell 法 (FMLC 法) を用いた測定では, de Klark ら”は, 透析 導入前慢性腎不全患者, 血液透析患者共に, 正常対昭群 より血清 EPO が低值であったとしているが，他の報告 では，血液透析患者において，EPO值が高いとしている ものや8,9), 両者の間で差が認められないとしているもの もあり ${ }^{10)}$ ，一致を見ていない. RIAによる測定は最近ま でその知見に乏しく，検討している症例数も限られてい

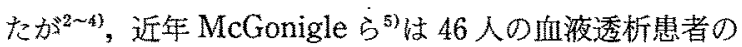
血清 $\mathrm{EPO}$ 濃度を測定し, $31.9 \pm 1.9 \mathrm{mU} / \mathrm{m} l$ (mean士 $\mathrm{SEM})$ と正常群 $(23.1 \pm 1.0 \mathrm{mU} / \mathrm{m} l)$ に比較して有意に 高値であったことを報告している.今回のわれわれの研 究に扔いても; 血液透析患者の平均血獎 $\mathrm{EPO}$ 濃度は, 対照群と比較して有意に上昇していた。

各原因疾患別にみた貧血及び EPO 濃度の検討に扔い ては, McGonigle ら ${ }^{5)}$ は, PCD 患者は, 他の原因の慢性 腎不全患者より有意に末梢血へマトクリット值が高いと 報告して抢り，またChandra ら ${ }^{23)}$ は，12人の PCD が 原因で血液透析中の患者と, 24 人の他の原因による血液 透析患者を比較して，PCD 患者の方が血清 $\mathrm{EPO}$ が有意 に高く, 負血の程度も軽度であると報告している。本研 究でも, 血獎 $\mathrm{EPO}$ 濃度は PCD 患者のみが他の疾患が 原因となっている慢性腎不全患者と比較して有意に高 く, 他疾患では対照群と此較しても有意な差が認められ なかった。 Chandra らは，この原因として，PCD では 腎組織が囊胞による圧迫を受けることにより, 組織中の 酸素分圧が低下して, EPO の産生が増加すると述べてい る. 我々の結果では, PCD と他疾患の間に末梢血へマト クリット值では差がみられなかったが，やはり PCD 患 者と他の患者では，腎臓の EPO 産生に差があると考え られた。

一般の貧血症の場合, 貧血が進行するとともに血中 $\mathrm{EPO}$ 濃度が増加する傾向が認められるが4), 今回の我々
の研究では, 血液透析患者の末梢血へマトクリット値及 びへモグロビン濃度と血漿 $\mathrm{EPO}$ 濃度は, 現在までの報 告 ${ }^{5 \sim 87}$ と同様に明らかな相関が認められなかった。このよ うに血液透析を受けている慢性腎不全患者の血墏 EPO 濃度は，正常対照と比較して必ずしも低值ではないが貧 血の程度に対して反応しないということから，慢性腎不 全患者の相対的な $\mathrm{EPO}$ 濃度の低下は, 腎の荒廃により $\mathrm{EPO}$ の産生機構が障害を受けるというよりも, 血流状態 等の変化淿よって組織内低酸素に対する反応性が低下す ることによって生じている可能性が示唆された. PCD 患 者では，この反応性が比較的良く保たれていると考党ら れる。

血液透析期間と血獎 $\mathrm{EPO}$ 濃度の間に正の相関が得ら れた理由は不明であるが, PCD 患者が比較的長い血液透 析歴を有していたということに関連があると思われた。

慢性靔不全患者の賽血の他の要因として血液中の造血 阻害物質の存在が以前より言われて故り，現在まで慢性 腎不全患者の血清が，赤血球の発育過程において，CFU -E (colony-foaming unit-erythroid) $ゃ \mathrm{BFU}-\mathrm{E}$ (burst -foaming unit-erythroid) の形成や，heme 合成を㸞制 することが報告されている ${ }^{14 \sim 17)}$.また，これらの抑制は， むしろ二次的なもので，この阻害物質は直接 $\mathrm{EPO}$ 亿作 用して，これを抑制するという説も見られる ${ }^{24)}$.しかし， その物質が何であるかは未怡完には同定されて扔ら ず，血清中の PTH が類似の阻害効果を持つという報告 や16), ボリアミンの一種である spermine が, in vitroで CFU-E の形成を抑制するという報告がみられ ${ }^{15)}$ ，これ らの物質である可能性が示唆されている。

現在，慢性腎不全患者に対する $\mathrm{rEPO}$ 投与はその貧血 の予防あるいは治療法として大きな期待が持たれてい る. しかし，以上の RIA による慢性腎不全患者の血漿 $\mathrm{EPO}$ 濃度の測定結果は, 必ずしも rEPO 投与のみです べての筫血が改善されないことを示すものと考元られ る.したがって, 血中 EPO 濃度が高値の症例について は，他の腎性貧血の原因と考えられているものに対する 対応が，重要であると考えられる。

\section{結論}

1 人 rEPO 家鬼に兔疫して得られた抗 EPO 抗体 を用いた RIA 法により，血液透析中の HD 患者及び正 常対照者の血漿 EPO 濃度を測定した。

2 正常対照者の血漿 $\mathrm{EPO}$ 濃度は, $13.3 \pm 0.4 \mathrm{mU} / \mathrm{m} l$ (mean土SEM) であった.

$3 \mathrm{HD}$ 患者の血漿 $\mathrm{EPO}$ 濃度は, $19.4 \pm 3.0 \mathrm{mU} / \mathrm{m} l$ (mean \pm SEM) であり，正常対照者と比較して有意に高 值であった。

$\mathrm{HD}$ 患者の血漿 $\mathrm{EPO}$ 濃度と性，年齢，末梢血へマト 
クリット值，へモグロビン濃度との間に明らかな関係は みられなかったが，血液透析期間が長いほど血漿 EPO 濃度が高い傾向が認められた。

$4 \mathrm{HD}$ 患者の原因疾患による血漿 $\mathrm{EPO}$ 濃度の比較 では, PCD 患者が他の慢性腎不全患者よりも有意に高値 を示した。

\section{文献}

1) Fisher JV : Mechanism of anemia of chronic renal failure. Nephron $25: 106-111,1980$

2) Cotes $\mathrm{PM}:$ Immunoreactive erythropoietin in serum. Br J Haematol 50 : 427-438, 1982

3) Sherwood JB, Goldwasser E:A radio-immunoassay for erythropoietin. Blood $54: 885-893$, 1979

4) Zaroulis CG, Hoffman BJ, Kourides A : Serum concentrations of erythropoietin measured by radioimmunoassay in haematologic disorders and chronic renal failure. Am J Haematol 11 : 85-92, 1981

5) Mcgonigle RJS, Husserl F, Wallin JD, Fisher JW : Hemodialysis and continuous ambulatory peritoneal dialysis effects on erythropoiesis in renal failure. Kidney Int $25: 430-436,1984$

6) Garo J, Brown S, Miller O, Murray T, Erslev AJ : Erythropoietin levels in uremic nephric and anephric patients. J Lab Clin Med $93: 449-458$, 1979

7) de Klerk G, Wilmink JM, Rosengarten PCJ, Vet RJWM, Goudsmit R: Serum erythropoietin (ESF) titers in anemia of chronic renal failure. J Lab Clin Med 100 : 720-734, 1982

8) Radtke HW, Claussner A, Erbes PM, Scheuerm ann EH, Schopeppa W, Koch KM : Serum erythropoietin concentration in chronic renal failure : Relationship to degree of anemia and excretory renal function. Blood $54: 877-884,1979$

9) Fukushima $Y$, Fukuda M, Yoshida K, Yamaguchi A, Nakamoto Y, Miura AB, Harada T, Tsuchida $\mathrm{S}$ : Serum erythropoietin levels and inhibitors of erythropoietin in patients with chronic renal failure. Tohoku J exp 150:1-15, 1986.

10) Summerfield GP, Gyde HB, Forbes AMW, Goldsmith HJ, Bellingham AJ : Haemoglobin concentration and serum erythropoietin in renal dialysis and transplant patients. Scand J
Haematol $30: 389-400,1983$

11) Jacobs $K$, Shoemaker $C$, Rudersdorf $R$ : Isolation and characterizaton of genomic and cDNA clones of human erythropoietin. Nature $313: 806-810$, 1985

12) Garcia JF, Sherwood J, Goldwasser E : Radioimmunoassay of erythropoietin. Blood Cells $5: 405$ $-419,1979$

13) Radtke HW, Frei U, Erbes PM, Shoeppe W, Koch $\mathrm{KM}$ : Improving anemia by hemodialysis : Effect on serum erythropoietin. Kidney Int $17: 382-387$, 1980

14) Delwiche F, Segal GM, Eschbach JW, Adamson JW : Hematopoietic inhibitors in chronic renal failure : Lack of in vitro specificity. Kidney Int $29: 641-648,1986$

15) Radtke HW, Rege AB, LaMarche MD, Bartos D, Barots F, Campbell RA, Fisher JW : Identification of spermine as an inhibitor of erythropoiesis in patients with chronic renal failure. J Clin Invest $67: 1623-169,1981$

16) McGonigle RJS, Wallin JD, Husserl F, Deftos LJ, Rice JC, O'neil WJ, Fisher JW : Potential role of parathyroid hormone as an inhibitor of eryth. ropoiesis in the anemia of renal failure. J Lab Clin $104: 1016-1026,1984$

17) Moriyama $Y$, Rege A, Fisher JW : Studies on an inhibitor of erythropoiesis. II. Inhibitory effect of serum from uremic rabbit on heme synthesis in rabbit bone marrow culture. Proc Soc Exp Biol Med 148: 94-97, 1975

18) Shaw $A B:$ Haemolysis in chronic renal failure. Br Med J 2 : 213-244, 1967

19）高久史麿：腎不全とエリスロポイエチン.日本臨床, $32: 528-534,1974$

20) Eschbach JW, Adamson JW : Anemia of end -stage renal disease (ESRD). Kidney Int $28: 1-5$, 1985

21) Winearls CG, Oliver DO, Pippard MJ, Reid C, Downing MR, Cotes PM : Effect of human erythropoietin derived from recombinant $\mathrm{DNA}$ on the anaemia of patients maintained by chronic haemodialysis. Lancet : 1175-1178, 1986

22) Eschbach JW, Egrie JC, Downing MR, Browne JK, Adamson JW : Correction of the anemia of end-stage renal disease with recombinant human 
erythropoietin. N Eng J Med $316: 73-78,1987$

23) Chandra M, Miller ME, Garcia JF, Mossey RT, McVicar $M$ : Serum immunoreactive erythropoietin levels in patients with polycystic kidney disease as compared with other hemodialysis patients. Nephron $39: 26-29,1985$

24) Mcgonigle RJS, Wallin JD, Shadduck RK, Fisher $\mathrm{JW}$ : Erythropoietin deficiency and inhibition of erythropoiesis in renal in sufficiency. Kidney Int $25: 437-444,1984$ 